\title{
Sciendo
}

\section{ESTIMATION OF CONDITIONS IN EXCHANGEABLE JAWS DESIGN OF PNEUMATICS GRIPPER}

\author{
Marcela BUČÁNYOVÁ, Erika HRUŠKOVÁ, Miriam MATÚŠOVÁ, \\ Martina KUSÁ \\ SLOVAK UNIVERSITY OF TECHNOLOGY IN BRATISLAVA, \\ FACULTY OF MATERIALS SCIENCE AND TECHNOLOGY IN TRNAVA, \\ INSTITUTE OF PRODUCTION TECHNOLOGIES, \\ UliCa JÁna BotTu 2781/25, 91724 TRNAVA, SLOVAK REPUBLIC \\ e-mail: marcela.bucanyova@stuba.sk, erika.hruskova@stuba.sk,miriam.matusova@stuba.sk, \\ martina.kusa@stuba.sk \\ Received: 04.06.2018, Accepted: 04.07.2018, Published: 19.09.2018
}

\begin{abstract}
The paper deals with the design of replaceable jaws on pneumatics gripper of the CNC milling machine EMCO Concept MILL 105, which is part of the iCIM 3000 manufacturing and assembly system. When designing replaceable jaws to allow firm and safe clamping of rotating and non-rotating parts, it was based on limiting factors such as parameters of the pneumatics gripper, dimensions, shape and material of the clamped parts and the like.
\end{abstract}

\section{Key words}

Milling, component base, changeable jaws, pneumatics gripper

\section{INTRODUCTION}

The complete design of the preparation takes into account several requirements such as technological operation, shape and dimensions of the component, material of the components, splinters. There are also clamps with replaceable parts, such as pneumatic gripper, where only replaceable jaws are designed.

The EMCO Concept MILL 105 CNC milling machine, which is part of the iCIM 3000 production and assembly system, is a pneumatic gripper from GRESSEL Ecopos with replaceable jaws. The paper deals with the individual steps of designing the replaceable jaws for a new component base.

\section{CURRENT STATE IN THE MILLING MACHINE}

At present, the EMCO Concept MILL 105 CNC milling machine machining of rotating parts with diameter $\varnothing 30 \mathrm{~mm}$ and $\varnothing 40 \mathrm{~mm}$. 


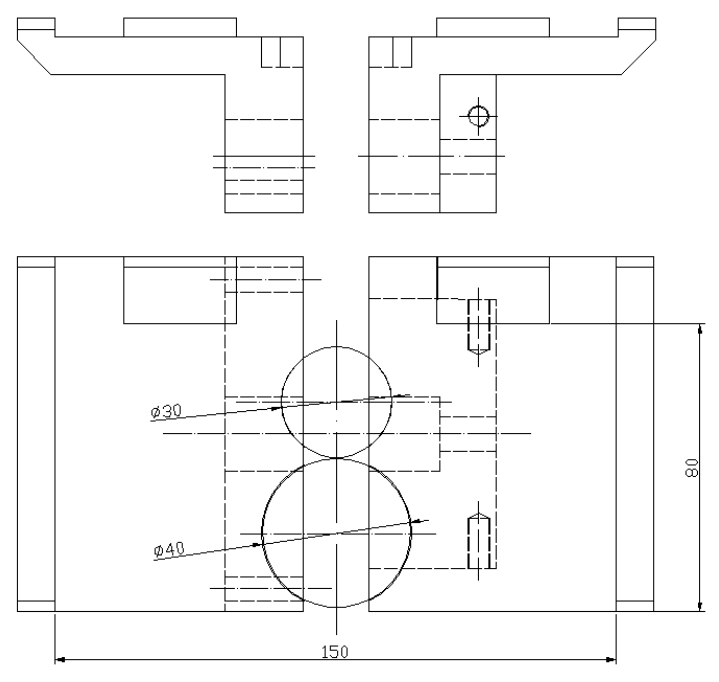

Fig. 1 Current state of replaceable jaws in pneumatics gripper

These rotating parts are clamped in clamping jaws, which also serve to clamp a plateshaped component with dimension 80x150x14.8mm (Fig.1). All machined parts are made of aluminium. Replaceable jaws are clamped on a pneumatic spindle with a maximum clamping length of $70 \mathrm{~mm}$ and a jaw width of $72 \mathrm{~mm}$. This size is also adjustable for jaws.

\section{NEW COMPONENT BASE AND DESIGN OF REPLACEABLE JAWS IN THE PNEUMATICS GRIPPER}

The milling machine is designed to produce rotating components with a diameter of $32 \mathrm{~mm}$ and a non-rotating components with dimensions 60x140x14.8 mm (Fig.2). New rotary parts and plates are also made of aluminium.

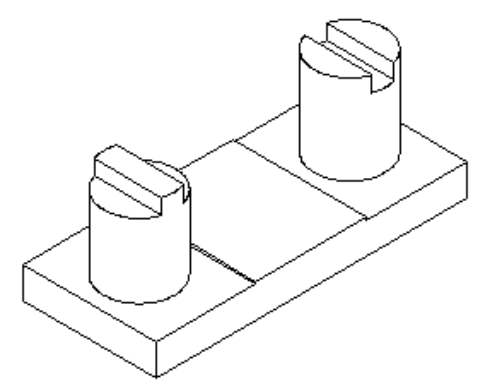

Fig. 2 New component base

For the new component base, replaceable jaws are designed to allow firm and secure clamping of rotating and non-rotating components. At the same time, the jaws of the pneumatic gripper cannot clamp the new parts because their dimensions and shapes are different. The clamping of the rotating parts will be up to $8 \mathrm{~mm}$ in height, which ensures a firm and reliable clamping at a total height of $35 \mathrm{~mm}$. The insufficient maximum clamping length of the pneumatic gripper affects the shape of the replaceable jaws.

\section{Dimensions design of fixture parts of replaceable jaws to the gripper}

The clamping parts of the replaceable jaws consist of the design of two groups of dimensions. These are the diameters of the jaws for clamping the jaws with screws and the 
spacing between holes for clamping the jaws through the screws (Fig. 3). These dimensions are influenced by the pneumatic sprocket.

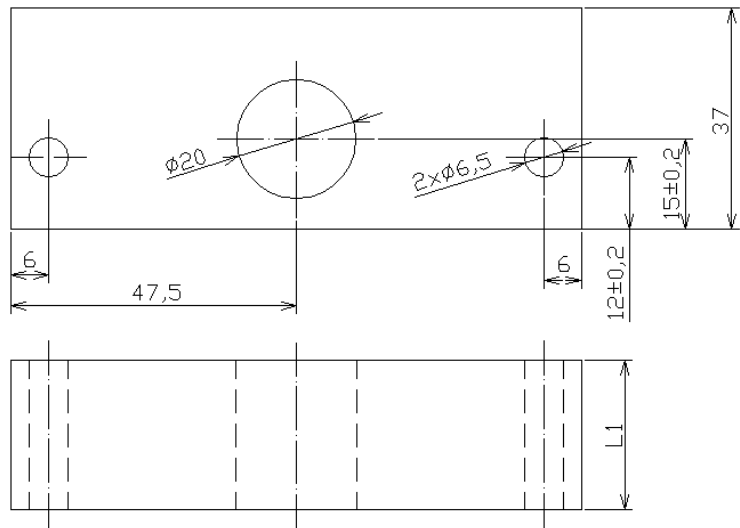

a)
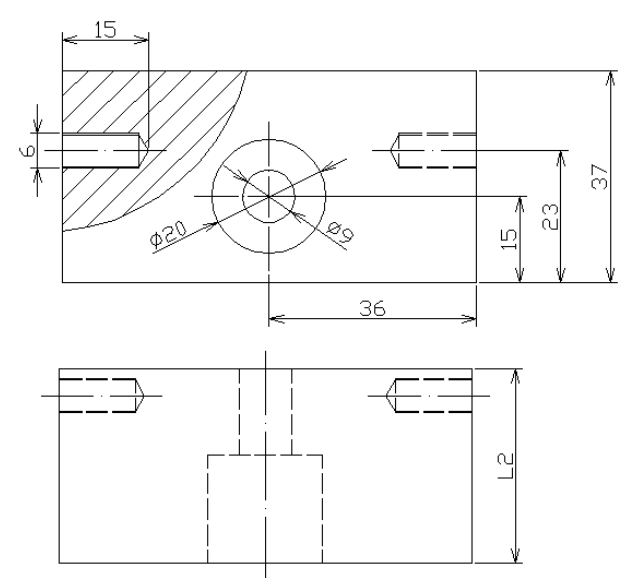

b)

Fig. 3 Fixture part of jaws to the pneumatics gripper a) left jaw, b) right jaw

The most important parameter that affects the dimensions L1 and L2 is the maximum clamping length of the pneumatic gripper, which is $70 \mathrm{~mm}$ and the clamping stroke of the pneumatic gripper, the value of which can be selected in the range of 1 to $5 \mathrm{~mm}$.

The clamping stroke determines the distance that the jaws move when they are snapped and tipped. In this case, the distance of $7 \mathrm{~mm}$ jaws (Fig. 4) and $11 \mathrm{~mm}$ jaws was determined. Thus, the clamping stroke is $4 \mathrm{~mm}$. Dimensions L1 and L2 can be determined on the basis of the opening and clamping stroke of the pneumatic gripper. The total width of the left and right jaw represents $59 \mathrm{~mm}$. Based on the design, the width of the left jaw was $\mathrm{L} 1=25 \mathrm{~mm}$ and the width of the right jaw $\mathrm{L} 2=34 \mathrm{~mm}$.

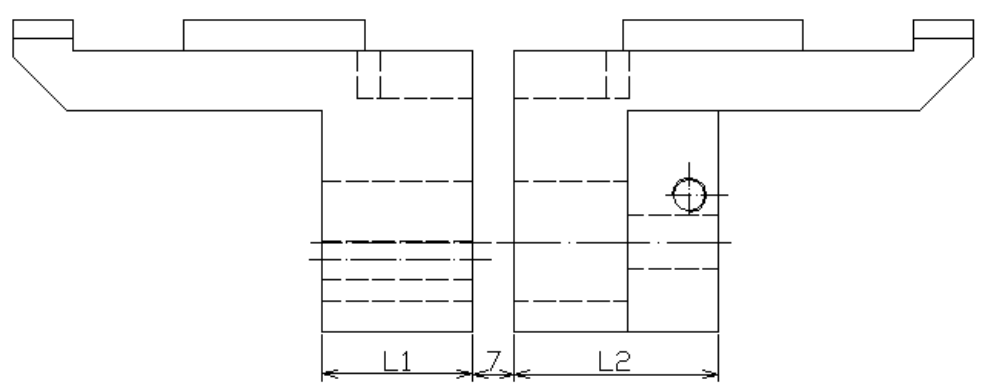

Fig. 4 Mutual dimension of replaceable closed jaws which are fixture in pneumatics gripper

\section{Design dimensions of fixture part of replaceable jaws for base plates}

Clamping of plates $60 \times 140 \times 14.8 \mathrm{~mm}$ is high up to $5 \mathrm{~mm}$. The dimensions $1_{1}$ and $l_{2}$ are given by the length of the plate from which the distance between the closed jaws is deducted. The sum of the lengths of the clamping parts of the left and right jaws for clamping plates is $133 \mathrm{~mm}$. On the basis of the design, the length of the clamping portion of the left jaw was $l_{1}=66.5 \mathrm{~mm}$ and the length of the right jaw clamping length $1_{2}=66.5 \mathrm{~mm}$ (Fig. 5).

The width of the left and right jaw clamps was determined to be $77 \mathrm{~mm}$ (Fig. 6) based on the base plate width of $60 \mathrm{~mm}$. 


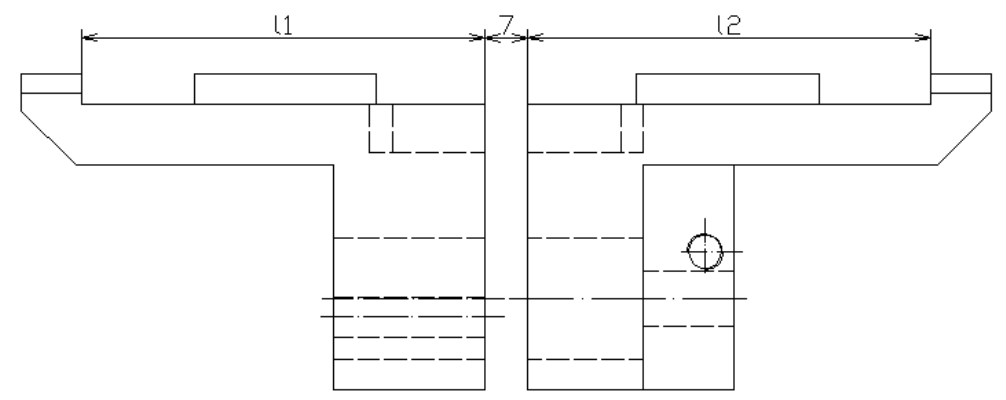

Fig. 5 Lengths of fixture parts of replaceable jaws

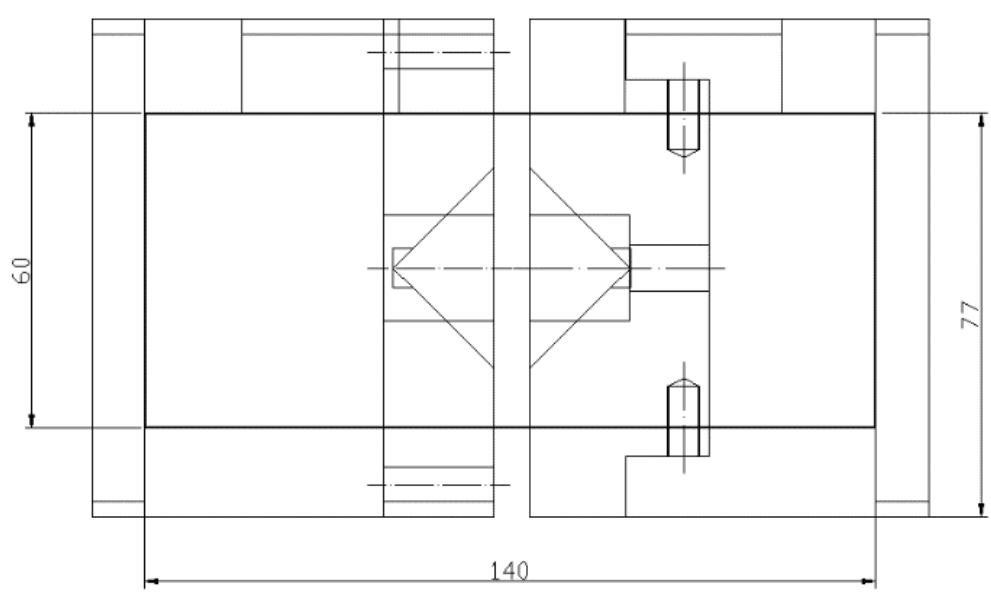

Fig. 6 Fixture of base plate in the replaceable jaws

\section{Dimensions design of prisms of replaceable jaws}

Prismatic jaws are designed to clamp the rotary workpieces. In this case, the prism angle $\alpha=90^{\circ}$ was also selected.

The prism design (Fig. 7) was based on the diameter of the clamped work piece D and the distance $h$, which represents the length of the prism, in this case determines the dimension of the clamping part for clamping the plate, i.e. $h=l_{1}$. The distance $h$ is an important value for determining the $\mathrm{H}$ value, which represents the distance of the edge of the clamping portion of the base plate from the component axis. The $\mathrm{H}$ value is defined by:

$$
H=h+0,707 \times D-0,5 \times C \quad[\mathrm{~mm}],
$$

where:

$h$ - flexible part dimension for fixture of base plate [mm],

$D$ - workpiece diameter [mm],

$C$ - width of prism [mm].

If the value $\mathrm{C}$ is not known, it can be based on the $\mathrm{L}_{z \mathrm{C}}$ value, which represents the distance between the clamped jaws and its value is $7 \mathrm{~mm}$. In this case, the relation for $\mathrm{H}$ is determined as:

where:

$$
H=h+\frac{L_{Z \check{C}}}{2} \quad[\mathrm{~mm}],
$$

$L_{z \check{c}}$ - dimension between closed jaws [mm].

Based on the previous relationship (1) it is possible to derive the relationship for determining the prism width $\mathrm{C}$ in the form: 


$$
C=2 \times(h-H+0,707 \times D) \quad[\mathrm{mm}]
$$

Dimensions SA and SB (Fig. 7) are defined by relationships:

$$
\begin{gathered}
S B=\frac{D}{2} \quad[\mathrm{~mm}] \\
S A=\frac{S B}{\sin \frac{\alpha}{2}} \quad[\mathrm{~mm}],
\end{gathered}
$$

where:

$\alpha$ - angle of prism $\left[^{\circ}\right]$.

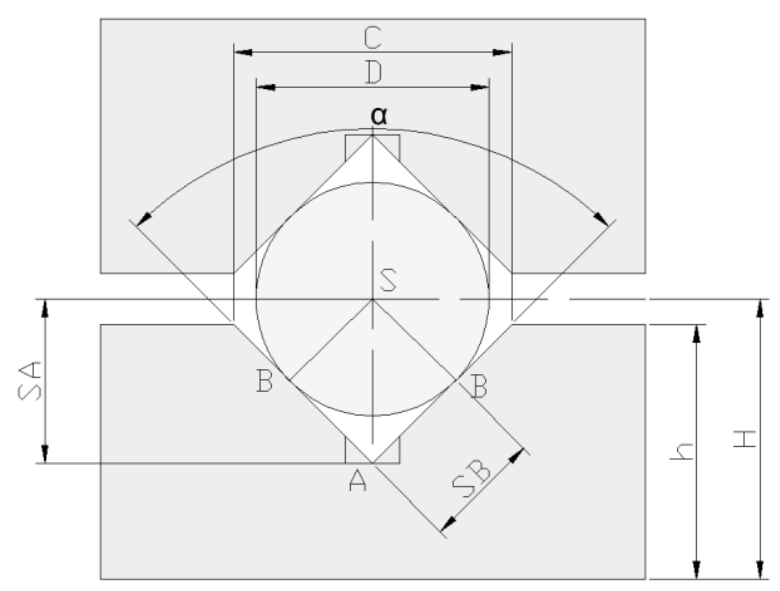

Fig. 7 Base dimensions of prism

According to previous relations, the basic prism dimensions for the rotary components with diameter $\varnothing 32 \mathrm{~mm}$ (Tab. 1) were calculated. The designed replaceable prisms are shown in Fig. 8.

Table 1: Base dimensions of prism

\begin{tabular}{|c|c|c|c|c|c|c|}
\hline $\begin{array}{l}\text { Diameter of fixtured } \\
\text { workpieces D [mm] }\end{array}$ & $\alpha\left[^{\circ}\right]$ & $\mathrm{h} \mathrm{[ \textrm {mm } ]}$ & $\mathrm{H}[\mathrm{mm}]$ & $\mathrm{C}[\mathrm{mm}]$ & $\mathrm{SB}[\mathrm{mm}]$ & $\mathrm{SA}[\mathrm{mm}]$ \\
\hline$\varnothing 32$ & 90 & 66.5 & 70 & 38.3 & 16 & 22.6 \\
\hline
\end{tabular}

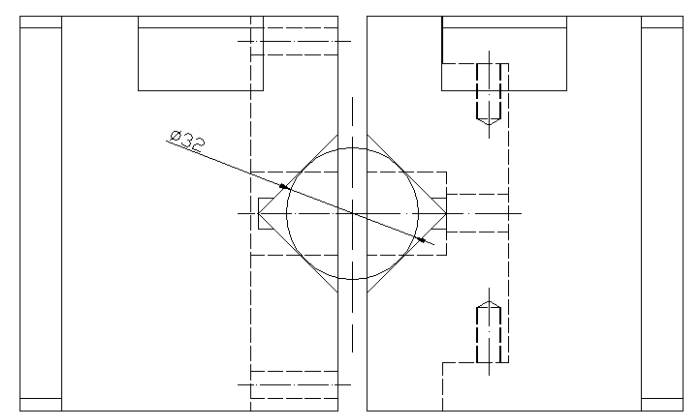

Fig. 8 Replaceable jaws for workpieces ø $32 \mathrm{~mm}$ 


\section{Selection of suitable material for removable jaws}

Steel with a minimum tensile strength about $450 \mathrm{MPa}$, is one of the most commonly used materials for the jaws' jaws. The chosen material was therefore the E360 (11 700) structural steel, suitable for machine parts that have higher resistance to wear and tear.

\section{Determining the size of the clamping force}

The size of the clamping force is an important parameter for machining. The clamping force must be greater than the cutting force so that the workpiece is not displaced or vibrated. The pneumatic sprocket used has a maximum clamping force of $3000 \mathrm{~N}$, which means that the cutting force must be smaller.

Determination of the size of the cutting force consists of the following steps:

- Selection of a suitable cutting tool

- Determination of cutting conditions

- Calculation of the cross section of the fragments taken

- Determination of cutting resistance

- Calculation of the cutting force size

- Determination of the safety factor

- Determination of the size of the clamping force

The size of the clamping Fu force can be determined by:

$$
F u \geq \frac{K \times F c}{f}[\mathrm{~N}]
$$

The coefficient of friction $f$ between the workpiece and the clamping surfaces of the preparation. Its value depends on the surface of the preparation and the machining of the workpiece.

The clamping forces required to clamp the rotating components and plates have been calculated. All values were below max. The clamping force which the pneumatic claw is able to clamp.

\section{CONCLUSION}

The aim was to design replaceable jaws on the GRESSEL Ecopos pneumatic gripper clamped on the EMCO Concept MILL 105 CNC milling table. The new jaws were designed to ensure firm clamping and setting up of newly-formed rotating components with ø $32 \mathrm{~mm}$ diameter and a 60x140x14.8mm (WxLxH) baseplate.

The design of jaws was based on limiting factors, such as the parameters of a pneumatic gripper as a maximum and minimum cutting, maximum clamping force, maximum clamping stroke, clamping screw spacing and others. Another important design factor was also the size, shape and material of the parts. For the versatile use of the pneumatic gripper, the shape of the designed jaws has been adapted to the gripper parameter. When designing replaceable jaws, their dimensions were proposed, which were divided into three groups. These groups consist of the dimensions of the clamping parts of the replaceable jaws, the clamping part of the replaceable jaws for the base plates and the dimensions of the jaws of the replaceable jaws.

The chosen material was E360 structural steel (11 700). To design the components and base plates, it was necessary to determine the size of the clamping force. The required size of the clamping force must be less than the maximal clamping force of the gripper. After calculating the clamping forces, it was found that all the components and base plates could be securely clamped on the pneumatic gripper. 


\section{Acknowledgement}

This paper for written thanks to the project named "Laboratory of flexible manufacturing systems with robotized manipulation supported by drawing-free production“. Project was supported by ASFEU agency through the structural funds of EU.
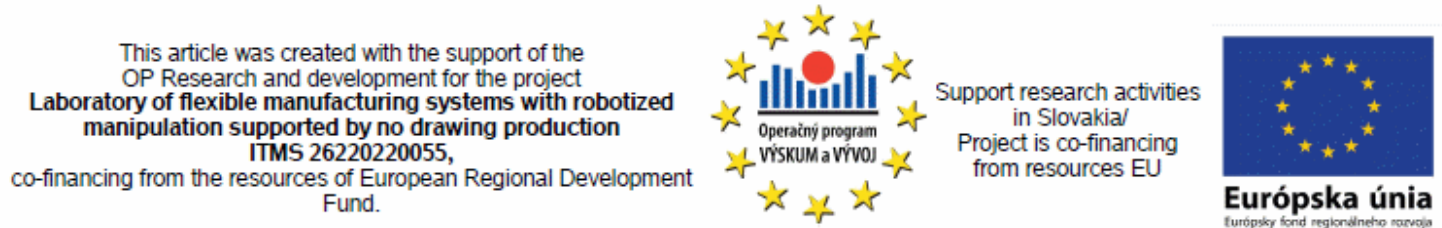

\section{References:}

1. CHVÁlA, B., VOTAVA, J. 1988. Př́pravky. (Fixtures), Praha, SNTL a Alfa. ISBN 04-240-88

2. RUŽAROVSKÝ, R., DELGADO SOBRINO, D. R. HOLUBEK, R., KOŠŤÁL, P. 2014. Automated in-process inspection method in the flexible production system iCIM 3000. Applied Mechanics and Materials: Novel Trends in Production Devices and Systems II. Special topic volume with invited peer reviewed papers only, Vol. 693, pp. 50-55. ISSN 1660-9336

3. POKORNÝ, P., VÁCLAV, Š. 2008. Ustavenie a upnutie montážneho prípravku. (Positioning and clamping of assembly JIG = Positioning and clamping of assembly JIG). Vedecké práce MtF STUv Bratislave so sídlom v Trnave. Research papers Faculty of Materials Science and Technology Slovak University of Technology in Trnava, No 24, pp.131-136. ISSN 1336-1589

4. MORAVČÍIKOVÁ, J., VÁCLAV, Š. 2017. Návrh komponentov upínacieho stavebnicového systému. (Components design of modular fixture system.) In: Skúmanie vplyvu vybraných charakteristík procesu obrábania s využitím Hi-technológii obrábania na výslednú kvalitu obrábaných plôch a bezproblémovú montáž [elektronický zdroj] : Proceedings of the domestic reviewed papers. 1st edition. Trnava: AlumniPress, pp. 204-212. ISBN 978-80-8096-244-9

\section{ORCID:}

Marcela Bučányová

Erika Hrušková

Miriam Matúšová

Martina Kusá
0000-0002-4427-8018

0000-0003-4852-7824

0000-0002-2128-3041

0000-0002-4816-3349 